\title{
Nanostructural Materials for Energy Storage Systems
}

\author{
Bronislaw Buczek \\ Faculty of Energy and Fuels, AGH University of Science and Technology, 30 Mickiewicza Avenue, 30-059 Cracow, Poland \\ Correspondence should be addressed to Bronislaw Buczek, bbuczek@agh.edu.pl
}

Received 31 August 2010; Revised 9 November 2010; Accepted 24 December 2010

Academic Editor: Mohamed Sabry Abdel-Mottaleb

Copyright (c) 2011 Bronislaw Buczek. This is an open access article distributed under the Creative Commons Attribution License, which permits unrestricted use, distribution, and reproduction in any medium, provided the original work is properly cited.

\begin{abstract}
The aim of this study was to assess of carbonaceous monoliths used for adsorption cooling systems. The carbonaceous monoliths prepared from coal precursors are obtained. The porous structure of monoliths was evaluated on the basis of nitrogen adsorptiondesorption data. The investigated monoliths have significantly developed microporous structure. The large specific area of carbonaceous monoliths (about $2000 \mathrm{~m}^{2} / \mathrm{g}$ ) and volume of micropores are observed. Methanol adsorption isotherms and heat of wetting using methanol was determined. Results show that monoliths materials are high adsorption capacity of methanol and heat of wetting, which can improve of heat exchange and efficiency in processes of refrigeration and air conditioning.
\end{abstract}

\section{Introduction}

Processes of mass and energy storage with application of microporous adsorbent can be included into prospective directions of the adsorption technology development. The application of carbonaceous adsorbents for heat storage can be used in adsorptive refrigerators utilizing closed thermodynamic cycles [1]. The most interesting system is methyl alcohol and microporous carbon material pair [2]. Because of its ability to selectively adsorb vapours and gases, extended internal porosity, and large specific surface area, active carbon is a good adsorbent for storage of mass and energy [3]. Methanol is more easily desorbed, and its working pressure is always lower than atmospheric pressure, which allows for a rapid identification of any faults in a cooling system. The temperature of desorption of methanol from an adsorbent is considerably lower than for water vapour systems. For all these reasons the methanol-active carbon pair can be used for mass and energy storage.

The wide developing techniques of solar heating with use of different types of solar collectors found the use also in adsorption cooling system. The adsorption cooling system with solar collector was presented in Figure 1.

The performance of an adsorbent in a thermodynamic system depends upon properties such as specific area, type and number of pores, adsorbent form, and adsorption enthalpy of the adsorbate and its thermal conductivity. Therefore, any method of modification of active carbon has to improve carbon structural features and to increase the heat and mass transfer [4].

The good adsorbent should have not only developed microporous structure but also large bulk density, which improve packing and heat conductivity on adsorbent bed [5]. It depends on shape of adsorbent: powder, granular, or disk monolith $[6,7]$. We can increase the packing up of the particles in order to prepare microporous monoliths and simultaneously to increase heat conductivity of its bed.

Active carbon-methanol pair appears to be suitable for different adsorptive cooling systems. This pair can be successfully used as fridge for storage of food and medicines and ice manufacture, in air conditioning devices and heat pumps [8].

\section{Experimental and Results}

Investigations were carried on four carbonaceous monoliths. The aim of this study was to assess the monoliths used for adsorption cooling systems. The carbonaceous monoliths prepared from hard coal precursors are obtained from Faculty of Chemistry, Wroclaw University of Technology [9]. Preparations of carbon monoliths are presented in Figure 2. 


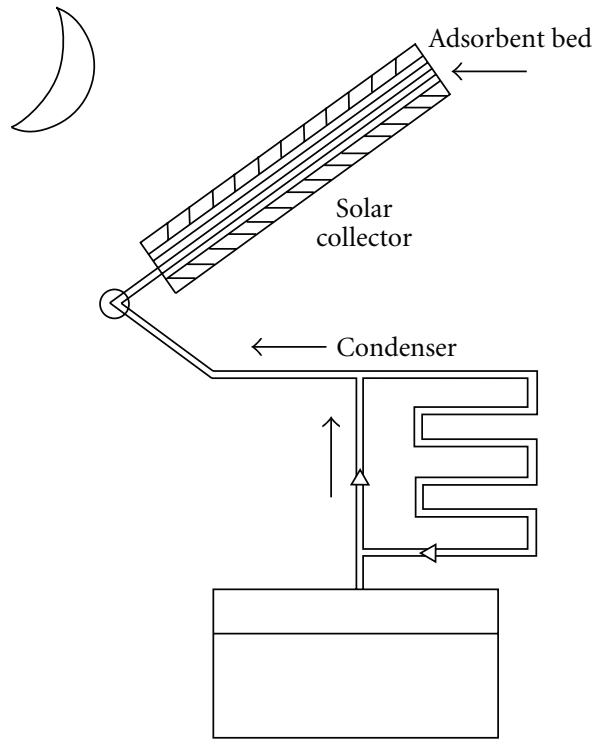

Evaporator

(a)

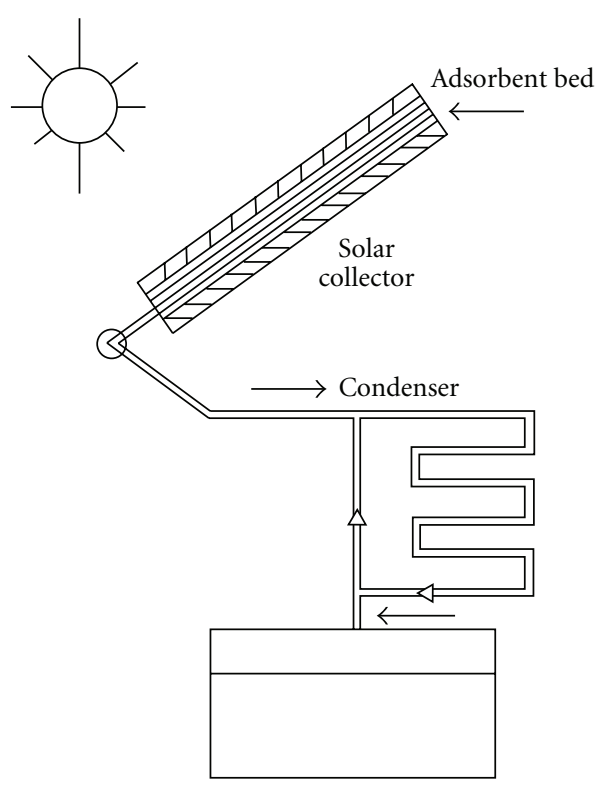

Evaporator

(b)

Figure 1: Scheme of adsorption solar refrigerator [8].

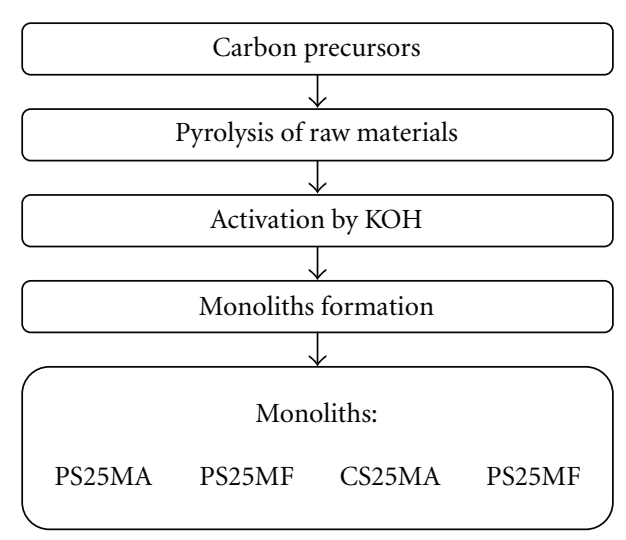

Figure 2: Preparation of carbon monoliths.

TABLE 1: Raw material characteristic of monoliths.

\begin{tabular}{lll}
\hline Monoliths & Carbon precursors & Binder \\
\hline \multirow{2}{*}{ PS25MA } & $\begin{array}{l}\text { Semicoke from coal pitch } \\
\text { from coking plant }\end{array}$ & $\begin{array}{l}10 \% \text { polyvinyl alcohol } \\
\text { (PVA) }\end{array}$ \\
PS25MF & Makoszowy & $\begin{array}{l}10 \% \text { polyvinylidene } \\
\text { fluoride (PVDF) }\end{array}$ \\
\hline CS25MA & Semicoke from coal from & $\begin{array}{l}7,5 \% \text { PVA } \\
\text { CS25MF }\end{array}$ \\
\hline
\end{tabular}

Powder product of activation by $\mathrm{KOH}$ was mixed with polymer binder, and then tablet was formed by $18 \mathrm{~mm}$ diameter and $7-10 \mathrm{~mm}$ height. The technological characteristic and designation monoliths are presented in Table 1.

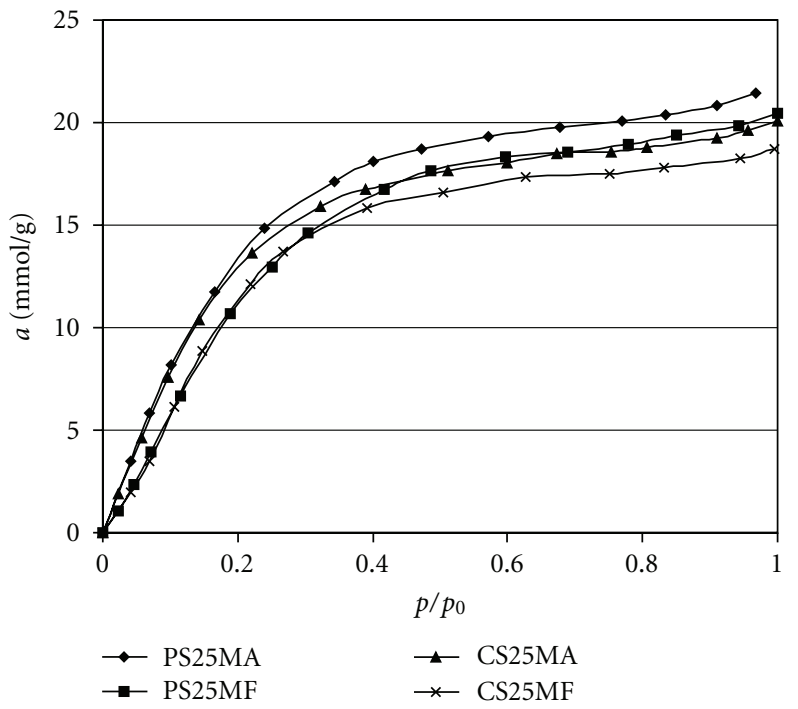

Figure 3: Methanol adsorption isotherms of monoliths.

2.1. Analysis of Porous Structure. The porous structure of monoliths were evaluated on the basis of nitrogen adsorption-desorption data. Isotherms were determined by a volumetric method using the Sorptomatic 1900 apparatus. Measurements were taken at a temperature of $77.5 \mathrm{~K}$, and range of pressure was $p / p_{0}=0.00001-0.999$. The volumes of micropores $\left(W_{0}\right)$ and characteristic energy of adsorption $\left(E_{0}\right)$ have been determined according to DubininRadushkevich equation [10], and specific surface area was obtained using the BET equation [11]. Total volume of micropores $\left(V_{p}\right)$ has been read for nitrogen adsorption 


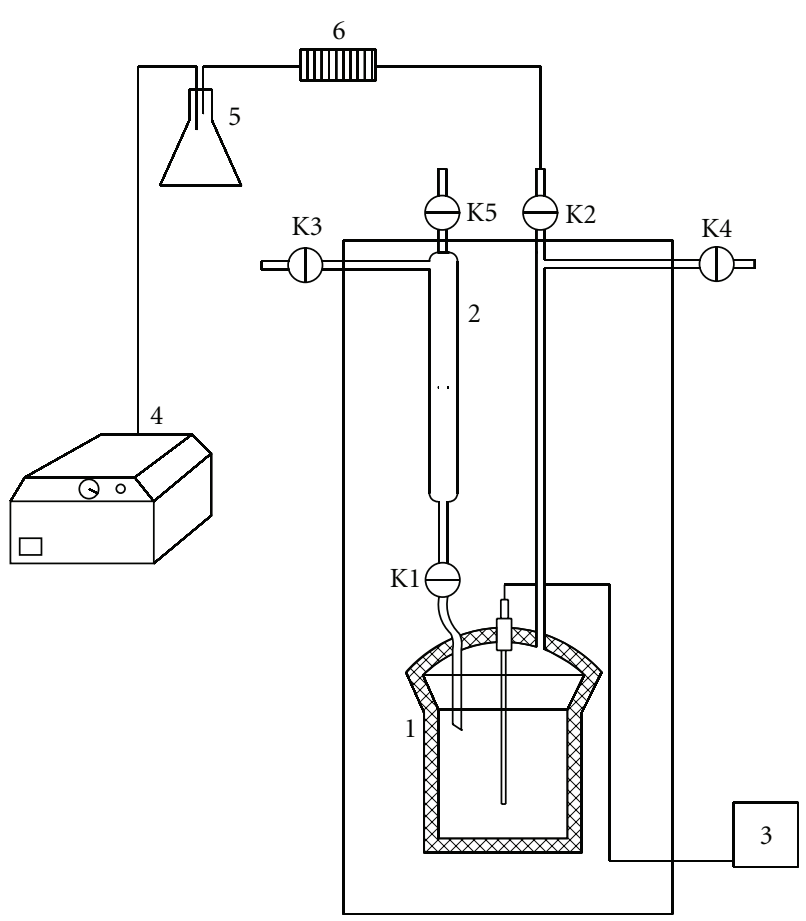

FIGURE 4: Scheme of equipment for measuring the heat of wetting: 1-calorimetric cell, 2-container of methanol, 3-electronic system to temperature measurement, 4-vacuum pump, 5-control vessel, 6filter.

TABLE 2: Structural properties of monoliths.

\begin{tabular}{lcccc}
\hline Monolith & $W_{0} \mathrm{~cm}^{3} / \mathrm{g}$ & $E_{0} \mathrm{~kJ} / \mathrm{mol}$ & $S_{\text {BET }} \mathrm{m}^{2} / \mathrm{g}$ & $V_{p} \mathrm{~cm}^{3} / \mathrm{g}$ \\
\hline PS25MA & 0.714 & 18.3 & 1910 & 0.925 \\
PS25MF & 0.672 & 18.1 & 1830 & 0.887 \\
CS25MA & 0.709 & 18.4 & 1880 & 0.876 \\
CS25MF & 0.689 & 18.4 & 1805 & 0.854 \\
\hline
\end{tabular}

isotherms of value $p / p_{0}=0.99$. The results of calculations are shown in Table 2.

The carbonaceous monoliths are characterized by significantly developed microporous structure. They achieved a large volume of micropores $\left(0.672-0.714 \mathrm{~cm}^{3} / \mathrm{g}\right)$ and very impressive specific surface area $\left(1805-1910 \mathrm{~m}^{2} / \mathrm{g}\right)$. The biggest microporous structure for monoliths formed with polyvinyl alcohol (PVA) is observed.

2.2. Methanol Adsorption. Methanol adsorption isotherms of monoliths were measured volumetrically. The measurements were carried out in the temperature $298 \mathrm{~K}$.

The adsorption isotherms of methanol vapours for monoliths are presented in Figure 3.

All of the samples readily adsorb methanol giving reversible isotherms of type I. Adsorption capacity decreases simultaneously when the temperature rises. It is characteristic for highly microporous adsorbent. The investigated monoliths have related structural proprieties, and the course of isotherms is very similar in whole range of pressures. The monolith PS25MA characterizes insensibly larger adsorptive
TABLE 3: Heat effect and heat of wetting of monoliths.

\begin{tabular}{lccc}
\hline Monoliths & $\Delta T$ & $Q, \mathrm{~J} / \mathrm{g}$ & $d T / d t$ \\
\hline PS25MA & 7.6 & 159.83 & 177.0 \\
PS25MF & 5.3 & 111.03 & 331.2 \\
CS25MA & 7.9 & 165.14 & 35.9 \\
CS25MF & 7.6 & 160.43 & 119.8 \\
\hline
\end{tabular}

capacity. It can be noticed also that larger methanol adsorptive capacity for monoliths with PVA as binder is observed.

2.3. Heat Effects. The important factor of designing systems of adsorptive refrigerating, decisive for their performance, is the thermal effects of the process. Energetic effects of adsorption can be directly determined by calorimetric measurements. They can also be estimated by computing methods from the adsorption isotherms measured at various temperatures (the isosteric heat of adsorption).

For the estimation of the energetic effects characterizing the investigated monoliths, the heat of their wetting by methanol has been determined. The heat of wetting, evolved as a result of the mutual interaction of the molecules of the wetting liquid and the adsorbent surface, is a valuable source of information. The measurements of the heat of wetting were carried out in the original apparatus, which is presented in Figure 4 [12].

For the estimation of the energetic effects characterizing the investigated monoliths, the heat of their wetting by methanol has been determined. The values of the heat of wetting $Q$, the values of the temperature increase $\Delta T, d T / d t$ are collected in Table 3.

Monoliths were characterized by significantly great energetic effects related to the heat of wetting with methanol. Heat effects and determined heat of wetting for monoliths are very high. The largest thermal effect $(165,14 \mathrm{~J} / \mathrm{g})$ as well as the quickest increase of temperature $(d T / d t=35,9)$ was noted down for monolith CS25MA. For monoliths what use polivinyl alcohol as binder (PS25MA, CS25MA) the larger heat of wetting than monoliths with polyvinylidene fluoride (PS25MF, CS25MF) is observed.

\section{Conclusion}

In this study, the porous structure of monoliths was analysed, and adsorption equilibrium and heat effects of wetting by methanol have been determined. We could evaluate of carbon monoliths used for adsorption cooling system.

Pyrolysis of raw materials (carbon precursors), activation by $\mathrm{KOH}$, and monoliths formation give us very attractive materials as an adsorbent for energy storage systems. The investigated monoliths have significantly developed microporous structure. The large specific area of carbonaceous monoliths (about $2000 \mathrm{~m}^{2} / \mathrm{g}$ ) and volume of micropores are observed. The methanol adsorptive capacity of all monoliths is also impressive.

Experimental results show that carbon monoliths materials have very high adsorption capacity of methanol and heat 
of wetting, which can improve heat exchange and efficiency in processes of cooling and air conditioning.

The carbonaceous monoliths are also characterized by large energetic effects related to the heat of wetting with methanol. All these advantages improve the performance and efficiency of the system in adsorptive refrigeration.

\section{Acknowledgment}

The authors are grateful to AGH (Project no. 11.11.210.125) for its financial support of this work.

\section{References}

[1] F. Meunier, "Adsorptive cooling: a clean technology," Clean Products and Processes, vol. 3, no. 1, pp. 8-20, 2001.

[2] A. P. F. Leite, M. B. Grilo, R. R. D. Andrade, F. A. Belo, and F. Meunier, "Experimental evaluation of a multi-tubular adsorber operating with activated carbon-methanol," Adsorption, vol. 11, no. 1, pp. 543-548, 2005.

[3] H. Marsh and F. Rodriguez-Reinoso, Activated Carbon, Elsevier, 2006.

[4] B. Buczek and E. Wolak, "Nanostructural active carbons from vegetable precursors for heat storage system," Chemical and Process Engineering, vol. 30, no. 1, pp. 173-180, 2009.

[5] G. Cacciola, G. Restuccia, and L. Mercadante, "Composites of activated carbon for refrigeration adsorption machines," Carbon, vol. 33, no. 9, pp. 1205-1210, 1995.

[6] B. S. Akkimaradi, M. Prasad, P. Dutta, and K. Srinivasan, "Effect of packing density and adsorption parameters on the throughput of a thermal compressor," Carbon, vol. 40, no. 15, pp. 2855-2859, 2002.

[7] J. Walendziejewski and J. Trawczyński, "Wplyw ksztaltu ziarna katalizatora HDS na jego wlasciwosci fizykochemiczne i aktywnosc hydroodsiarczajaca," Przem Chem, vol. 74, p. 138, 1993.

[8] E. Wolak and B. Buczek, "Kierunki badań i praktycznych zastosowań układu wȩgiel aktywny-metanol," Inżynieria $i$ Aparatura Chemiczna, vol. 6, pp. 11-16, 2005 (Polish).

[9] K. Kierzek, H. Machnikowska, G. Gryglewicz, and J. Machnikowski, "Methane storage capacity of monoliths made of activated carbons of different porosity development," in Proceedings of the International Conference on Coal Science and Technology (ICC\&T '07), Nottingham, UK, August 2007, (CDROM).

[10] M. M. Dubinin, "Adsorption properties and microporous structures of carbonaceous adsorbents," Carbon, vol. 25, no. 5, pp. 593-598, 1987.

[11] R. M. A. Roque-Malherbe, Adsorption and Diffusion in Nanoporous Materials, CRC Press, Taylor \& Francis, Boca Raton, Fla, USA, 2007.

[12] B. Buczek and E. Wolak, "Potassium hydroxide modified active carbon for adsorptive refrigerators," Adsorption, vol. 14, no. 23, pp. 283-287, 2008. 


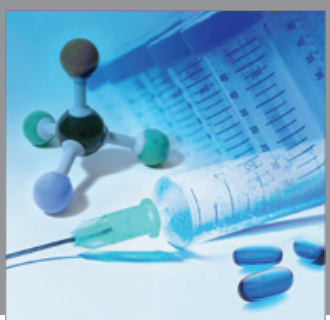

International Journal of

Medicinal Chemistry

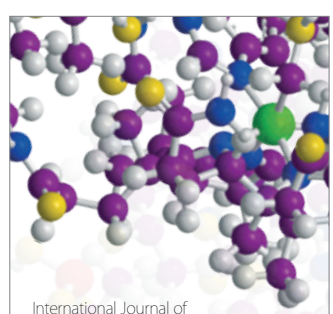

Carbohydrate Chemistry

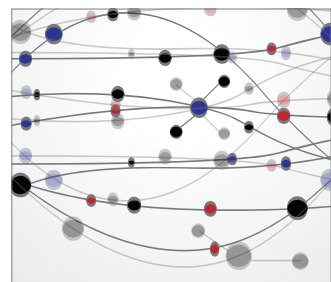

The Scientific World Journal
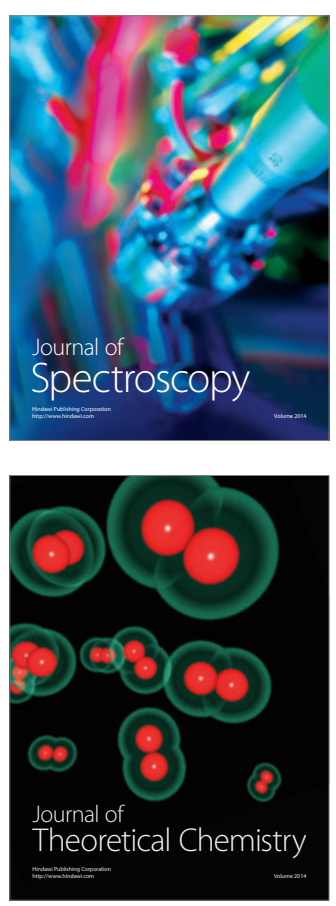
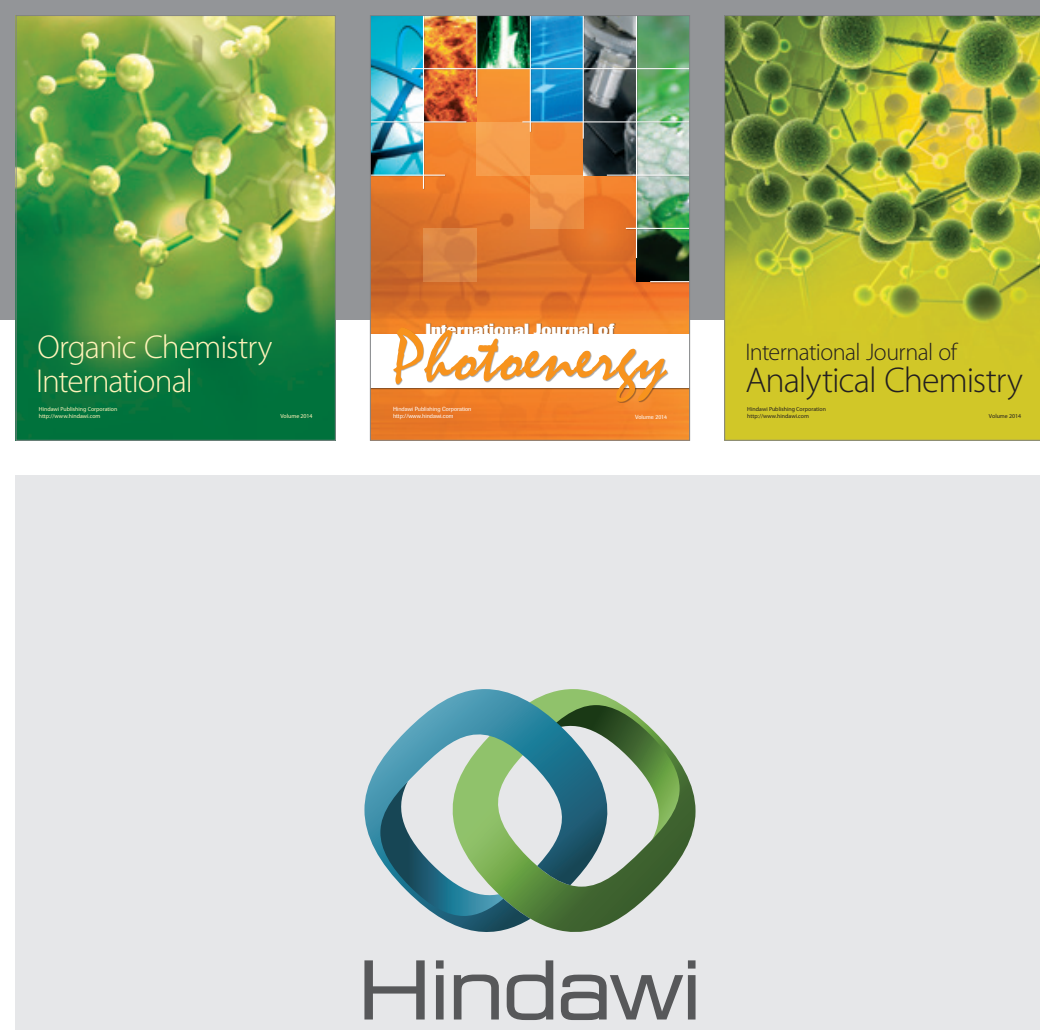

Submit your manuscripts at

http://www.hindawi.com
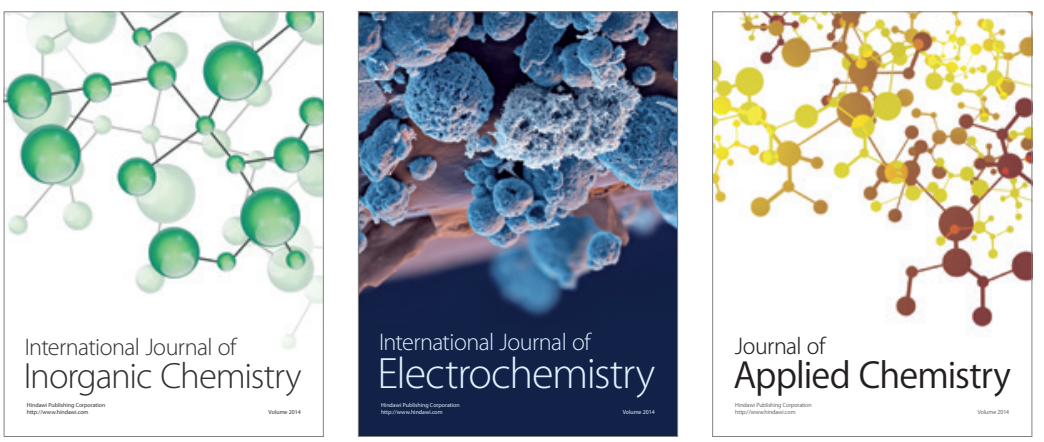

Journal of

Applied Chemistry
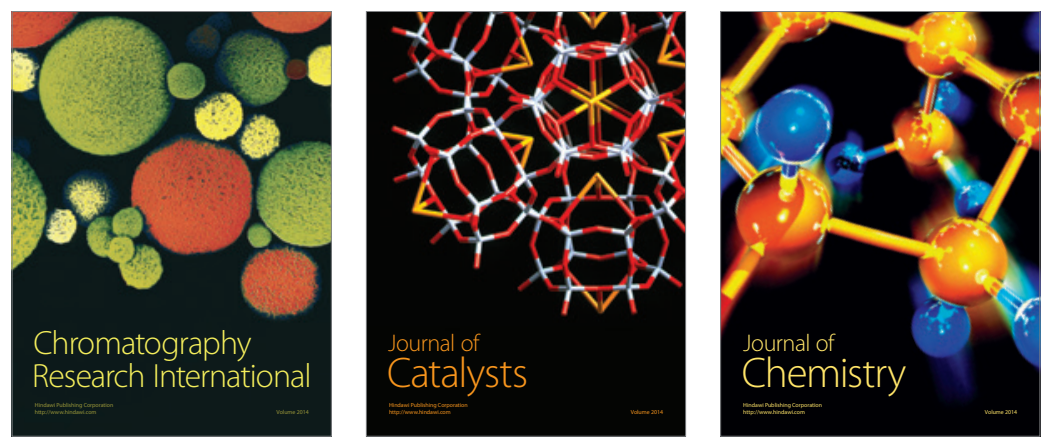
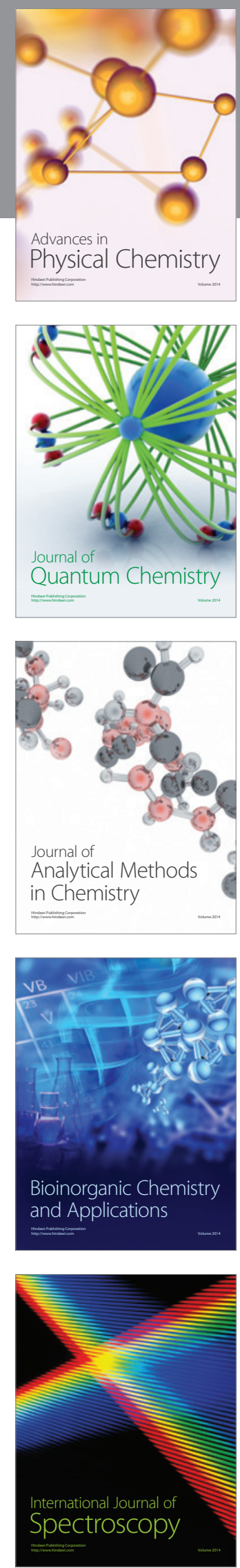